\title{
Mucinous tubular and spindle cell carcinoma kidney with sarcomatoid and rhabdoid differentiation- A rare entity
}

\author{
Fadiya Zainudeen', Umasankar .P2, Lakshmi Priya .U., ${ }^{3, *}$ Jayalakshmy P S ${ }^{4}$, Asiq Sideeque \\ 1,2,3 Assistant Professor, ${ }^{4}$ Professor, ${ }^{5}$ Professor and HOD, Dept. of Pathology, MES Medical College, Palachode P.O, \\ Perinthalmanna, Kerala, India \\ *Corresponding Author: \\ Email: lakshmipriyau@ymail.com
}

Received: $13^{\text {th }}$ November, 2017

Accepted: $17^{\text {th }}$ March, 2018

\begin{abstract}
Mucinous tubular and spindle cell neoplasm is a rare renal tumor with favourable outcome. Sarcomatoid change is described in many renal cell carcinomas, indicative of a worse clinical course. We report a case of mucinous tubular and spindle cell neoplasm with areas having sarcomatoid and rhabdoid morphology with large areas of necrosis. Sarcomatoid change is very rare in mucinous tubular and spindle cell tumor and we could find only 4 similar cases in the published literature.
\end{abstract}

Keywords: Mucinous tubular and spindle cell, Sarcomatoid, Rhabdoid.

\section{Introduction}

Mucinous tubular and spindle cell neoplasm is a rare renal tumor included in 2004 WHO classification of renal tumors. ${ }^{1}$ It was first described as an entity by Mac Lennan et al in 1997. ${ }^{2}$ They described the lesion as "low-grade mucinous tubulocystic renal carcinoma" in a series of 13 cases, morphologically different from all other renal tumors known at that time. They also proposed that the tumor is of collecting duct origin. The tumor is characterized by histological features such as tubules and cords of composed of low grade cuboidal cells, mucinous extracellular stroma and low grade spindle cell areas. The neoplasm is generally considered as low grade with good prognosis. However rare cases of metastatic MTSCC have been reported. ${ }^{3,4}$ Cases showing neuroendocrine differentiation are also described. 5 There are also reports of mucin poor variant, diagnosis of which causes considerable diagnostic chalange for histopathologist. ${ }^{7}$

Sarcomatoid transformation is well documented and can be seen in about $8 \%$ of common histological types of renal cell carcinomas. $^{8}$ Sarcomatoid morphology is usually associated with poor prognosis. High grade spindle cell areas in MTSCC are extremely rare.

\section{Case Report}

45 year old male presented with history of hematuria for two months. Ultrasound and CT scan revealed an upper pole lesion involving the left kidney (Fig. 1A). Left radical nephrectomy was done. Cut section revealed a well defined neoplasm involving the upper pole (Fig. 1B). Tumor had a variegated appearance with areas of necrosis, hemorrhage and cystic change. Tumor was seen infiltrating into renal sinuses. Perinephric fat and renal vessels were grossly free of neoplasm. No lymph nodes were identified grossly.

Microscopic examination in H\&E sections had the characteristic tubules, interlacing cords, trabeculae and papillae of low grade cuboidal cells with extracellular mucinous material in between (Fig. 2 A, C). Mucin was brightly stained using alcian blue (Fig. 2D). Areas with low grade spindle morphology was seen in between (Fig. 2B). There were also mucin poor areas. Also seen were areas with spindle cell morphology having marked atypia (Fig. 3A), necrosis (Fig. 3B) and frequent mitosis. Rhabdoid morphology was seen in areas (Fig. 3C). Vessels walls had prominent hyalinization (Fig. 3D). In areas cells had plasmacytoid morphology, arranged as whorls, resembling 'squamoid morules' (Fig. 3E). Geographic necrosis with palisading of tumor cells surrounding the vessels were noticed in areas. Bizarre cells and multinucleate tumor giant cells were present. (Fig. 3A inset). Areas also had collections of foamy macrophages and cholesterol clefts. There were areas with sclerosis and calcification. In areas tubules were seen forming complex architecture resembling a glomerulus, surrounded by an empty space (Fig. 3F). There were areas with prominent lymphoplasmacytic infiltrate, in between the tumor cells and in areas perivascular.

Immunohistochemistry was done (Fig. 4). Tumor cells were positive for cytokeratin 7, cytokeratin 19 and AMACR (alpha methyl racemace coenzyme A). Vimentin showed bright positivity in sarcomatoid areas and was negative in low grade areas. Tumor cells were negative for CD10. Desmin was done on sections with rhabdoid morphology and was negative. 


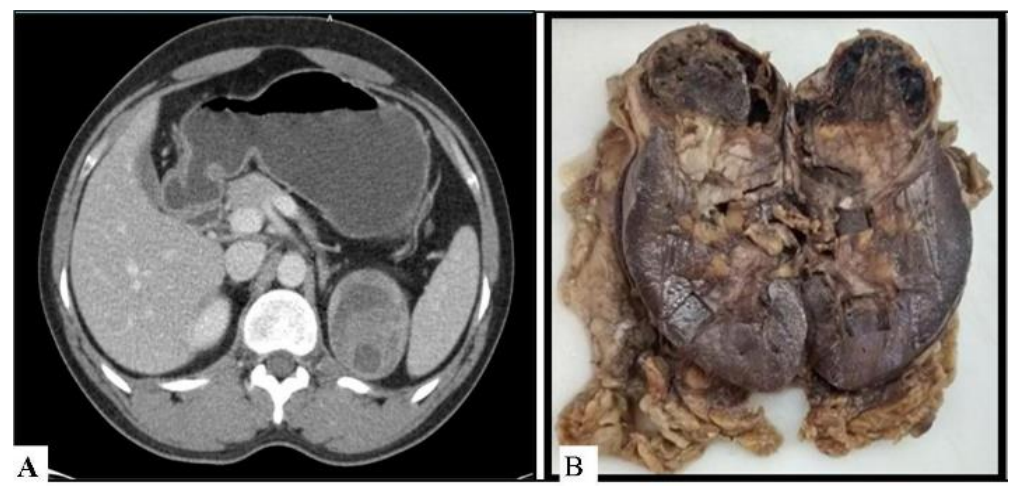

Fig. 1: A) CT scan with an upper pole lesion involving the left kidney; B) Nephrectomy showed well defined variegated neoplasm involving the upper pole

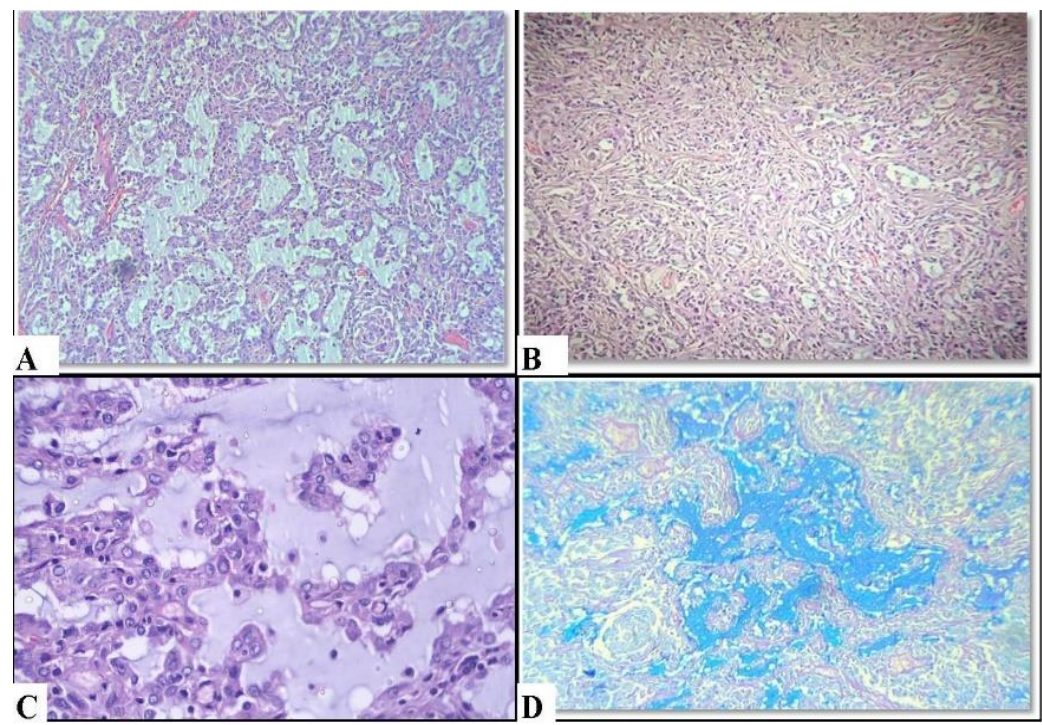

Fig. 2: A) Tumour cells arranged in cords with extracellular mucin in between(H\&E 100x); B) Areas with low grade spindle cell morphology(H\&E 100x); C) Tumour cells and mucin in high power(H\&E 400x); D) Alcian blue stain highlighted the mucin

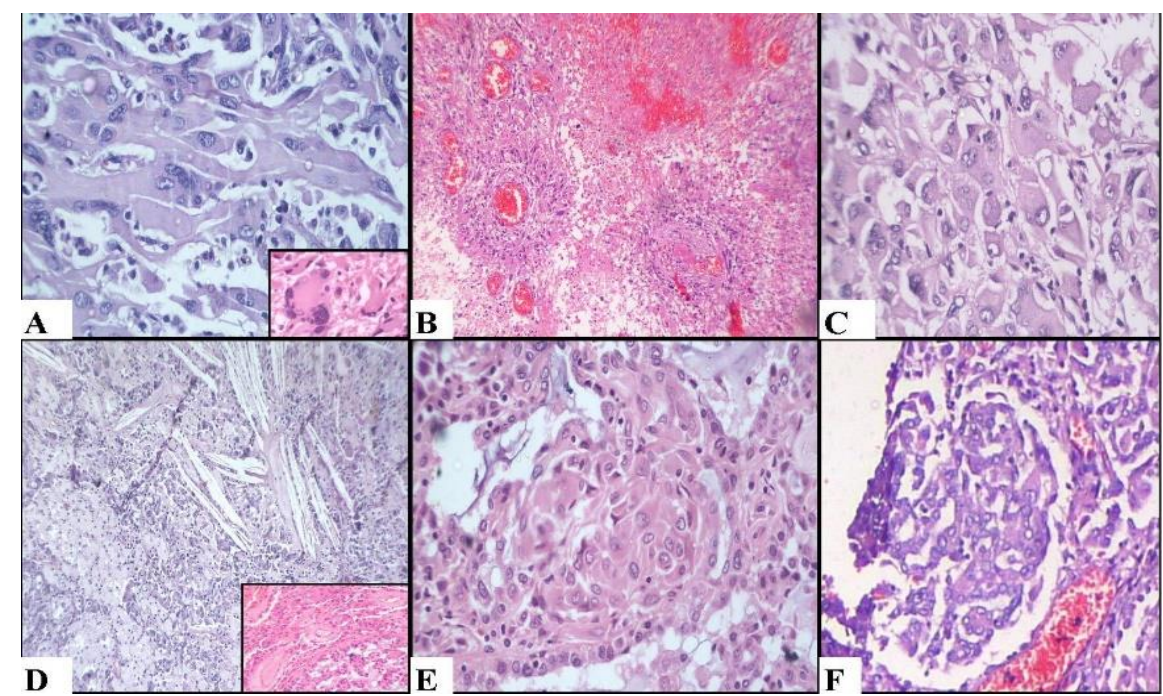

Fig. 3: A) Tumour cells with high grade spindle cell morphology(H\&E 400x); B) Areas of necrosis(H\&E 100x); C) Tumour cells with rhabdoid morphology(H\&E 400x); D) Areas with collections of foamy macrophages and cholesterol clefts and hyalinised vessels in inset(H\&E 100x); E) Squamoid morule formation(H\&E 400x); F) Tubules forming glomeruloid tufts(H\&E 400x) 


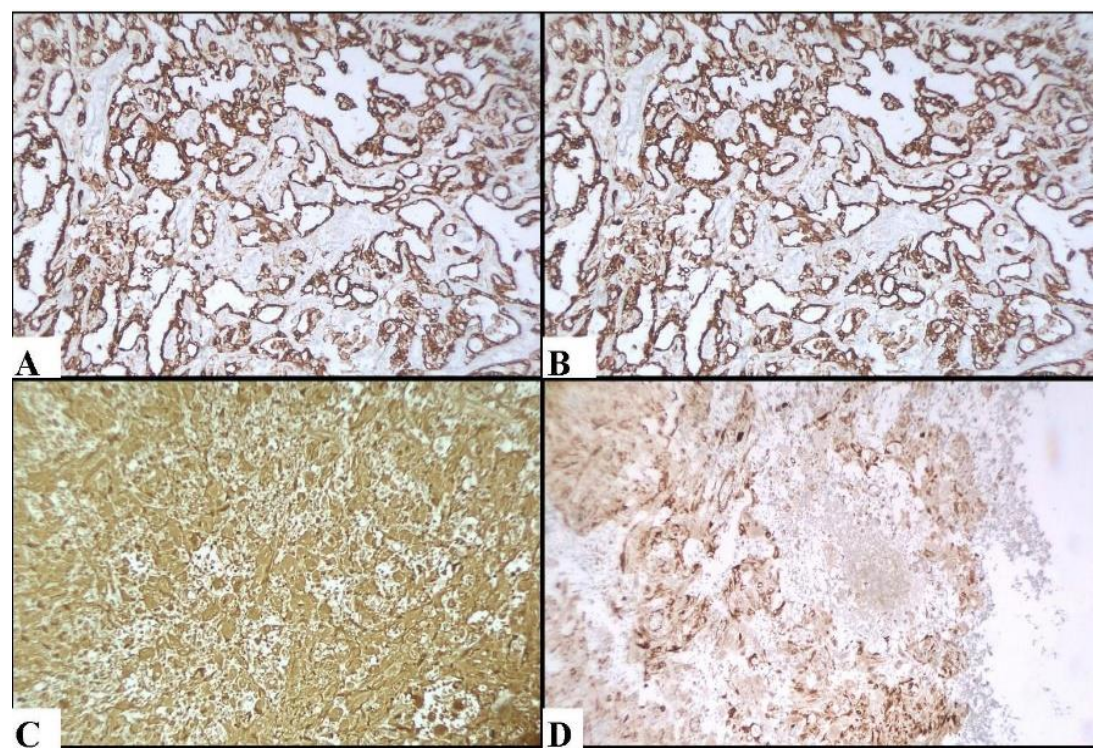

Fig. 4: A) Tumour cells showed strong positivity for CK 7; B) Tumour cells showed strong positivity for CK 19; C) Sarcomatoid areas positive for vimentin; D) Tumour cells positive for AMACR

\section{Discussion}

Since first described in case series in 1997 less than 100 cases of MTSCC could be identified in the published literature. ${ }^{2}$ Sarcomatoid transformation in MTSCC is extremely rare and was first described by Simon R.A et al in 2008. ${ }^{9}$ We could trace only four cases of sarcomatoid transformation in the published literature till date. Three out of these four case reports described aggressive courses with distant metastasis and fatal outcomes. ${ }^{9-12}$ Hence high grade sarcomatoid morphological features in MTSCC indicates poor prognosis.

MTSCC can show mucin poor areas as seen in this case. The mucin poor variant can cause considerable diagnostic challenge for the reporting pathologist. ${ }^{7,14}$ 'Glomeruloid' structures formed by complex tubules occupying an empty space seen in this case was also observed in a previous case report of MTSCC with neuroendocrine differentiation. ${ }^{15}$ Presence of foamy macrophages and prominent lyphoplasmacytic infiltrate were also described in published literature. ${ }^{13}$ However we could not identify any case reports of MTCC with tumor cells having rhabdoid or plasmacytoid morphology.

Low grade areas were positive for CK 7, CK 19, AMACR and was negative for CD10.Vimentin was expressed in sarcomatoid areas only. These observations were consistent with that of previous observations. ${ }^{10,13}$ There is no consensus regarding the ontogeny of MTSCC. Expression of AMACR, CK7 \& CK 19 suggests proximal tubular origin, similar to papillary renal cell carcinoma. Considering the overlap in the morphological and immunohistochemical features of both lesions, some researchers have a view that MTSCC is a variant of papillary RCC. ${ }^{16,17}$ However genetic analysis done by some researchers do not support this theory. ${ }^{18}$ Peckova $\mathrm{K}$ et al had proven that low grade MTSCC can have multiple genetic alterations such as losses affecting chromosomes 1, 4, $8,9,14,15$, and 22 . The study also proved tumors having morphological overlap with papillary RCC had more variable chromosomal changes including gains of both chromosomes 7 and 17, similar to papillary RCC. ${ }^{19}$

MTSCC is a rare renal neoplasm considered as low grade with favorable outcome. However this popular belief is now shaken by a few reports of metastasis and a few reports of high grade sarcomatoid change. Ursani NA et al and Thway $\mathrm{K}$ et al have described distant metastasis in cases with low grade MTSCC morphology. ${ }^{3,4}$ Some researchers had successfully attempted tyrosine kinase inhibitors like sunitinib in such cases. ${ }^{20}$ There are also reports of MTSCC with neuroendocrine differentiation. ${ }^{5}$ Larger worldwide studies are needed to understand more about the biological potential of MTSCC.

\section{References}

1. Eble JN, Sauter G, Epstein JI, Sesterhenn IA. The World Health Organization Classification of Tumours of the Urinary System and Male Genital System. Lyon, France: IARC Press;2004.

2. MacLennan GT, Farrow GM, Bostwick DG. Low-grade collecting duct carcinoma of the kidney: report of 13 cases of low-grade mucinous tubulocystic renal carcinoma of possible collecting duct origin. Urology. 1997 Nov;50(5):679-84

3. Ursani NA, Robertson AR, Schieman SM, Bainbridge T, Srigley JR. Mucinous tubular and spindle cell carcinoma of kidney without sarcomatoid change showing metastases to liver and retroperitoneal lymph node. Hum Pathol. 2011 Mar;42(3):444-8.

4. Thway K, du Parcq J, Larkin JM, Fisher C, Livni N. Metastatic renal mucinous tubular and spindle cell 
carcinoma. Atypical behavior of a rare, morphologically bland tumor. Ann Diagn Pathol. 2012 Oct;16(5):407-10.

5. Kuroda N, Nakamura S, Miyazaki E, Hayashi Y, Taguchi T, Hiroi M, Yamasaki Y, Shuin T, Enzan H. Low-grade tubular-mucinous renal neoplasm with neuroendocrine differentiation: a histological, immunohistochemical and ultrastructural study. Pathol Int. 2004 Mar;54(3):201-7.

6. Kuroda N, Hes O, Miyazaki E, Shuin T, Enzan H. Frequent expression of neuroendocrine markers in mucinous tubular and spindle cell carcinoma of the kidney. Histol Histopathol. 2006 Jan;21(1):7-10.

7. Farghaly H. Mucin poor mucinous tubular and spindle cell carcinoma of the kidney, with nonclassic morphologic variant of spindle cell predominance and psammomatous calcification. Ann Diagn Pathol. 2012 Jan;16(1):59-62.

8. de Peralta-Venturina M, Moch H, Amin M, et al. Sarcomatoid differentiation in renal cell carcinoma. Am J Surg 2001;25:275-84.

9. Simon RA, di Sant'agnese PA, Palapattu GS, Singer EA, Candelario GD, Huang J, Yao JL. Mucinous tubular and spindle cell carcinoma of the kidney with sarcomatoid differentiation. Int J Clin Exp Pathol. 2008 Jan 1;1(2):180-4

10. Arafah M, Zaidi SN. Mucinous tubular and spindle cell carcinoma of the kidney with sarcomatoid transformation. Saudi J Kidney Dis Transpl. 2013 May;24(3):557-60.

11. Pillay N, Ramdial PK, Cooper K, Batuule D. Mucinous tubular and spindle cell carcinoma with aggressive histomorphology--a sarcomatoid variant. Hum Pathol. 2008 Jun;39(6):966-9.

12. Dhillon J, Amin MB, Selbs E, Turi GK, Paner GP, Reuter VE. Mucinous tubular and spindle cell carcinoma of the kidney with sarcomatoid change. Am J Surg Pathol. 2009 Jan;33(1):44-9.

13. Zhao M, He XL, Teng XD. Mucinous tubular and spindle cell renal cell carcinoma: a review of clinicopathologic aspects. Diagn Pathol. 2015 Sep 17;10:168.

14. Fine SW, Argani P, DeMarzo AM, Delahunt B, Sebo TJ, Reuter VE, Epstein JI. Expanding the histologic spectrum of mucinous tubular and spindle cell carcinoma of the kidney. Am J Surg Pathol. 2006 Dec;30(12):1554-60.

15. Jung SJ, Yoon HK, Chung JI, Ayala AG, Ro JY. Mucinous tubular and spindle cell carcinoma of the kidney with neuroendocrine differentiation: report of two cases. Am J Clin Pathol. 2006 Jan;125(1):99-104.
16. Paner GP, Srigley JR, Radhakrishnan A, Cohen C, Skinnider BF, Tickoo SK, Young AN, Amin MB. Immunohistochemical analysis of mucinous tubular and spindle cell carcinoma and papillary renal cell carcinoma of the kidney: significant immunophenotypic overlap warrants diagnostic caution. Am J Surg Pathol. 2006 Jan;30(1):13-9.

17. Shen SS, Ro JY, Tamboli P, Truong LD, Zhai Q, Jung SJ, Tibbs RG, Ordonez NG, Ayala AG. Mucinous tubular and spindle cell carcinoma of kidney is probably a variant of papillary renal cell carcinoma with spindle cell features. Ann Diagn Pathol. 2007 Feb;11(1):13-21.

18. Cossu-Rocca P, Eble JN, Delahunt B, Zhang S, Martignoni G, Brunelli M, Cheng L. Renal mucinous tubular and spindle carcinoma lacks the gains of chromosomes 7 and 17 and losses of chromosome $\mathrm{Y}$ that are prevalent in papillary renal cell carcinoma. Mod Pathol. 2006 Apr;19(4):488-93.

19. Peckova K, Martinek P, Sperga M, Montiel DP, Daum O, Rotterova P, Kalusová K, Hora M, Pivovarcikova K, Rychly B, Vranic S, Davidson W, Vodicka J, Dubová M, Michal M, Hes O. Mucinous spindle and tubular renal cell carcinoma: analysis of chromosomal aberration pattern of low-grade, high-grade, and overlapping morphologic variant with papillary renal cell carcinoma. Ann Diagn Pathol. 2015 Aug;19(4):226-31.

20. Larkin J, Fisher R, Pickering L, Thway K, Livni N, Fisher C, Gore M. Metastatic mucinous tubular and spindle cell carcinoma of the kidney responding to sunitinib. J Clin Oncol. 2010 Oct 1;28(28):e539-40.

How to cite this article: Zainudeen $F$, Umasankar .P, Lakshmi PU, Jayalakshmy PS, Sideeque A. Mucinous tubular and spindle cell carcinoma kidney with sarcomatoid and rhabdoid differentiation- A rare entity. Ind J Pathol Oncol, 2018;5(3):512-515. 